\title{
Temperature Effects and Thermodynamic Adsorption of Flouride on Activated Coconut Shell Carbon, Activated Montmorillonite Clay and Rice Husk Ash
}

\author{
Danbature Lamayi Wilson", Shehu Zaccheus, Fai Frederick Yirankinyuki, \\ Pipdok Solomon Kwarson \\ Chemistry department, Gombe State University, Gombe State, Nigeria
}

\author{
*Corresponding Author: Danbature Lamayi Wilson, Chemistry department, Gombe State University, \\ Gombe State, Nigeria
}

\begin{abstract}
The temperature dependency and thermodynamic properties adsorption of fluoride by activated coconut shell carbon, and activated rice husk ash were investigated. The studies were carried out at various temperatures of $303,313,323 \& 333 \mathrm{~K}\left(30^{\circ} \mathrm{C}\right.$ to $\left.60^{\circ} \mathrm{C}\right)$. The maximum removal percentages were found at the maximum temperature of the study which is $60^{\circ} \mathrm{C}$ for each adsorbent. Thus, the removal percentage of fluoride increases with the increase in temperature. And the maximum removal percentage were found to be 83.5, 81.7 and $73.1 \%$ for activated coconut shell carbon, activated montmorillonite and activated rice husk ash respectively. The value of the enthalpy change $(\Delta H)$ calculated from the slope were -28808.01, -19388.25, and -31335.47 (KJ/mole) for activated coconut shell carbon, activated montmorillonite and activated rice husk ash respectively. The negative values of $(\Delta H)$ indicate the exothermic nature of the process. The values of the entropy change, $(\Delta \mathrm{S})$ were found to be 123.62, 91.62 and $120.07(\mathrm{KJ} / \mathrm{mole} / \mathrm{K})$ for activated coconut shell carbon, activated montmorillonite and activated rice husk ash respectively. The positive values of entropy change suggest an increased randomness at the solid/liquid interface during the sorption of fluoride into the adsorbents. The average calculated Gibbs free $(\Delta \mathrm{G})$ were found to be $-67891.92,-48523.4$ and 69517.73 (kJ/mole). The negative values of Gibbs free energy suggests the spontaneous and feasibility of the process.
\end{abstract}

Keywords: Adsorption, Enthalpy, Entropy, Free energy, Temperature.

\section{INTRODUCTION}

There are two major effects of fluoride on drinking water viz beneficial and harmful effects on human health. Small amount of fluoride in drinking water is essential for bones and the formation of dental enamel in animals and humans [1]. Whereas at higher concentrations, fluoride causes irreversible demineralization of bones and teeth tissues known as dental and skeletal fluorosis [2]. Thus, fluoride $\left(\mathrm{F}^{-}\right)$contamination in drinking water has been recognized as one of the serious problems worldwide [3]. That is why Fluoride has been classified as one of the contaminant of water for human consumption by the World Health Organization (W.H.O), in addition to Arsenic and Nitrate which cause large-scale health problem [4].

Different methods of excess fluoride removal in water have been reported such as coagulation, precipitation [5, 6], reverse osmosis [7], ion exchange [8], and adsorption on to various adsorbents [9]. Among all these techniques, an adsorption method holds a strong potential in fluoride removal due to its key process features such as removal even at low fluoride concentration, high removal capacities, greater accessibility, economical, ease of operation and cost effectiveness [9].

Activated carbons are widely used as adsorbents for the removal of organic chemicals and metal ions of environments; air, gases, potable water and waste water [9]. [10] studies revealed that red soil pots have ability to remove fluoride, it was found that kaolinite clay when activated with acid has good defluoridation capacity. The sorption capacity of the acid activated clay for fluoride ranged between 0.0450 and $0.0557 \mathrm{mg} / \mathrm{g}$ at different temperatures. Montmorillonite has also been used as adsorbent for removal of fluoride in water, [11] and modification of montmorillonite using lanthanide, magnesium and manganese can increase the adsorption capacity for fluoride removal [12]. [13] conducted a 
comparative study for the removal of fluoride using activated silica gel (ASiG) and activated rice husk ash (ARHA) as adsorbents through batch studies. The authors reported that both adsorbents were efficient for uptake of fluoride at $\mathrm{pH} 2.0$ and contact time of $100 \mathrm{~min}$. ASiG was found to be more efficient than ARHA with an initial fluoride concentration of $5 \mathrm{mg} / \mathrm{L}$ with percentage removal efficiency of 88.30 and $96.7 \%$ for ARHA and ASiG respectively. Also, [14] conducted study on adsorbents like concrete, ragi seed powder, red soil, horse gram seed powder, orange peel powder, chalk powder, pineapple peel powder and multhani matti. Experimental set up was batch studies. Results indicated fluoride removal efficiency of $86 \%$ for chalk powder and pineapple peel powder $79 \%$ and $75 \%$ for horse gram seed powder. Percentage removal for ragi seed and red mud was found to be $65 \%$ and $71 \%$ respectively. Removal efficiency was recorded less for multhani mitti and concrete which was $56 \%$ and $53 \%$. The aim of this study was to evaluate temperature effects and thermodynamics properties of the adsorption of fluoride on activated coconut shell carbon, activated montmorillonite and activated rice husk ash.

\section{Materials ANd Methods}

\subsection{List of Apparatus/Reagents}

The apparatus used in this experiment were; weighing balance, filter paper(what man No-1), pipette(10ml), aluminium foil, $\mathrm{pH}$ meter, mortar and pestle, muffle furnace, hot plate (electric tung), measuring cylinder, oven, micrometer sieves, beakers, standard volumetric flasks, tap water, deionized water, test tubes, spatula, stirrer, hammer, masking tape, UV-spectrophotometer(model JENWAY 6300 ).

The reagents used were as follows: Hydrochloric acid $(\mathrm{HCl})$, Acetic acid $\left(\mathrm{CH}_{3} \mathrm{COOH}\right)$, SPADNS Reagent (2-parasulfophenylazo)-1,8-dihydroxy-3,6-naphthalene disulfanate), TISAB (Total Ionic Strength Adjustment Buffer), Sodium hydroxide $(\mathrm{NaOH})$, Fluoride ion of known concentration, Phosphoric acid $\left(\mathrm{H}_{3} \mathrm{PO}_{4}\right)$, Sulphuric acid $\left(\mathrm{H}_{2} \mathrm{SO}_{4}\right)$, Sodium fluoride $(\mathrm{NaF})$, Zirconyl chloride octahydrate, Sodium chloride $(\mathrm{NaCl})$, Sodium citrate, concentrated acetic acid.

\subsection{Preparation of Solution}

\subsubsection{Fluoride Standard}

$1000 \mathrm{mg} / \mathrm{L}$ stock solution was prepared by dissolving $2.21 \mathrm{~g}$ of $\mathrm{NaF}$ in $1 \mathrm{~L}$ of deionized water.

\subsubsection{Preparation of SPADNS Reagents}

A weighed amount of $0.192 \mathrm{~g}$ of SPADNS was dissolved in $100 \mathrm{ml}$ deionized water. Also $0.0266 \mathrm{~g}$ of zirconyl chloride octahydrate was dissolved in $25 \mathrm{ml}$ of deionized water and $20 \mathrm{ml}$ of $\mathrm{HCl}$ was added to the solution and the deionized water was added up to $100 \mathrm{ml}$ marked. The SPADNS reagent was obtained by mixing SPADNS and zirconyl chloride in equal volumes called SPADNS reagent which is stable for more than two years if stored away from light.

\subsubsection{Preparation of TISAB}

Exactly $5.8 \mathrm{~g}$ of chloride chloride and $1.2 \mathrm{~g}$ of sodium citrate were mixed and $50 \mathrm{ml}$ deionized water was added and shaken, $5.7 \mathrm{ml}$ of concentrated acetic acid was also added. The $\mathrm{pH}$ of the solution was then adjusted using $\mathrm{pH}$ meter by adding a solution of $5.0 \mathrm{~mol} / \mathrm{L} \mathrm{NaOH}(4.0 \mathrm{~g}$ in $10 \mathrm{ml})$ to give $\mathrm{pH}$ of 5.0-5.5 which is the ideal range for a working electrode sensitive to fluoride.

\subsubsection{Preparation of Phosphuric Acid $\left(\mathrm{H}_{3} \mathrm{PO}_{4}\right)$}

Preparation of $50 \% \mathrm{H}_{3} \mathrm{PO}_{4}$ was done by taking $50 \mathrm{ml}$ of Phosphoric acid and adding $50 \mathrm{ml}$ of deionized water in $100 \mathrm{ml}$ volumetric flask.

\subsubsection{Preparation of $1 \mathrm{M}$ Hydrochloric Acid ( $\mathrm{HCl}$ )}

This was prepared by taking $30.9 \mathrm{ml}$ of concentrated $\mathrm{HCl}$ into $1000 \mathrm{ml}$ volumetric flask and filled to the marked with distilled water.

\subsection{Collection and Preparation of Adsorbent}

\subsubsection{Sampling Collection}

The montmorillonite (clay) and rice husk were collected from Talasse town in Balanga L.G.A of Gombe state, while the coconut shell was obtained from Gombe main market in Gombe town of Gombe state. 


\subsubsection{Chemical Activation and Carbonization of Coconut Shell}

The coconut shells was cut into smaller sizes using hammer and then washed several times with tap water to remove soil and dirt, it was then dried in an oven at $110^{\circ} \mathrm{C}$ until constant weight was obtained for several hours.

The modified method of [15] was adopted. $70 \mathrm{~g}$ of coconut shell was weight and soaked into phosphoric acid $\left(\mathrm{H}_{3} \mathrm{PO}_{4}\right)$ in a beaker and heated for one hour (1 hour). It was then aged for 24 hours (one day) wrapped with aluminium foil in order to soaks the acid very well. After then, it was washed several times using tap water and distilled water to remove the acid and then oven dried for six hours at $110^{\circ} \mathrm{C}$.

The 70g activated coconut shell was placed in motar and wrapped with aluminium foil and then carbonized at $500^{\circ} \mathrm{C}$ for three hours $[16,17]$. It was carbonized in a murfle furnance model (M104) twice under same condition. Then the charcoal was ground and sieved using 105 mesh sizes and kept for analysis.

\subsubsection{Preparation of Montmorillonite (Clay)}

The montmorillonite (clay) was washed several times with tap water and then distilled water, it was also dried in an oven at $120^{\circ} \mathrm{C}$ for several hours until a constant weight was obtained and then air dried for another two hours.

The clay was then ground and $150 \mathrm{~g}$ of it was weight and refluxed in $500 \mathrm{~mL} 1 \mathrm{MHCl}$ at $120^{\circ} \mathrm{C}$ for one hour thirty minutes $\left(1 \frac{1}{2}\right.$ hours), it was then air dried for two days, ground and sieved using 105 mesh size and kept for analysis [18].

\subsubsection{Preparation of Rice Husk Ash (WRHA)}

Rice husk was collected from a rice mill in Talasse Balanga L G A in Gombe state. The rice husk obtained was thoroughly washed with tap water and then distilled water about five times to removes adhering soil and dirt and then dried in an oven at $80^{\circ} \mathrm{C}$ over night. $150 \mathrm{~g}$ of cleaned rice husk was refluxed with $1 \mathrm{MHCl}$ at $90^{\circ} \mathrm{C}$ for one hour. After the reaction, acid was completely removed from the rice husk by washing it distilled water several times. It was then dried over night in an oven at $110^{\circ} \mathrm{C}$ temperature.

The treated rice husk was calcined in a muffle furnance using motar wrapped with aluminium foil paper at $650^{\circ} \mathrm{C}$ for six hours; silica with higher degree of purity was obtained in the form of White Rice Husk Ash (WHRA) [19]

\subsection{Spectrophotometric Determination of Fluoride Using SPADNS Reagent (Indicator)}

$1000 \mathrm{mg} / \mathrm{L}$ stock solution was prepared by weighing $2.21 \mathrm{~g}$ of $\mathrm{NaF}$ dissolved in one litre (1L) deionized water. Various concentrations of $0,1,2,3,4$ and $5 \mathrm{mg} / \mathrm{L}$ were serially prepared for the standard curve respectively. For each test tube, $1 \mathrm{ml}$ of SPADNS reagent was added and the corresponding absorbance for each concentration was obtained and recorded using UVSpectrophotometer at a wave length of $570 \mathrm{~nm}$. The same procedure was followed for adsorption fluoride using activated coconut shell, montmorillonite and rice husk ash using UVSpectrophotometer. (Model JENWAY 6300).

For each adsorbent, five (5) different weights of the adsorbent; 0.5, 1.0, 1.5, 2.0 and $2.5 \mathrm{~g}$ was measured into five different conical flasks. For each flask, $25 \mathrm{ml}$ of the flouride solution (i.e $5 \mathrm{mg} / \mathrm{L}$ ) was added and agitated for $60 \mathrm{~min}$. (1 hour).After the required contact time, it was allowed to stand for two minutes for settling the adsorbent, it was then filtered using No 1 whatman filter paper. The filtrate was then analysed for residual fluoride concentration by SPADNS method.

The percentage removal of fluoride ion and amount adsorbed $(\mathrm{mg} / \mathrm{g})$ were calculated using the following equations

$$
\begin{aligned}
& \% \text { Removal }=\frac{C i-C e}{C i} \times 100 \\
& \text { Amount adsorbed }\left(\mathrm{q}_{\mathrm{e}}\right)=\frac{(C i-C e)}{m} v
\end{aligned}
$$


Where;

$\mathrm{C}_{\mathrm{i}}=$ initial concentration of the fluoride solution $(\mathrm{mg} / \mathrm{L})$

$\mathrm{C}_{\mathrm{e}}=$ equilibrium concentration of the fluoride solution $(\mathrm{mg} / \mathrm{L})$

$\mathrm{M}=$ mass of the adsorbent $(\mathrm{g})$

$\mathrm{V}=$ volume of the fluoride test solution (L).

\section{RESULTS AND DISCUSSION}

\subsection{Effect of Temperature for Activated Coconut Shell Carbon}

The effect of temperature was studied by conducting the experiment at different temperatures of $303,313,323$ and $333 \mathrm{~K}\left(30^{\circ} \mathrm{C}\right.$ to $\left.60^{\circ} \mathrm{C}\right)$ and optimum conditions; $5 \mathrm{mg} / \mathrm{L}$ of fluoride ion concentration, contact time of 50 minutes, fixed $\mathrm{pH}$ of 7 , dosage of $1.5 \mathrm{~g} / \mathrm{L}$, and results obtained, Table 1 , was plotted as percentage removal of the fluoride ion versus temperature as shown in figure 1 .

It is observed that with an increase in the temperature from 303 to $333 \mathrm{~K}\left(30^{\circ} \mathrm{C}\right.$ to $\left.60^{\circ} \mathrm{C}\right)$, the percentage removal of fluoride ion increases from $63.5 \%$ to $83.5 \%$. As the temperature increases, the thickness of the outer surface of the activated carbon adsorbent decreases and the kinetic energy of the fluoride ion decreases across the external boundary layer and internal pores of the activated carbon adsorbent.

Table1. Showing the result effect of temperature for activated coconut shell carbon

\begin{tabular}{|l|l|l|l|l|l|l|}
\hline Temp $\left({ }^{\circ} \mathrm{C}\right)$ & Absorbent $(\mathrm{g})$ & Time $(\mathrm{min})$ & $\mathrm{C}_{\mathrm{i}}(\mathrm{mg} / \mathrm{L})$ & $\mathrm{C}_{\mathrm{e}}(\mathrm{mg} / \mathrm{L})$ & $\mathrm{C}_{\mathrm{i}}-\mathrm{C}_{\mathrm{e}}(\mathrm{mg} / \mathrm{L})$ & $\%$ Removal \\
\hline 30 & 1.5 & 50 & 5 & 1.826 & 3.174 & 63.5 \\
\hline 40 & 1.5 & 50 & 5 & 1.304 & 3.696 & 73.9 \\
\hline 50 & 1.5 & 50 & 5 & 1.043 & 3.957 & 79.1 \\
\hline 60 & 1.5 & 50 & 5 & 0.826 & 4.177 & 83.5 \\
\hline
\end{tabular}

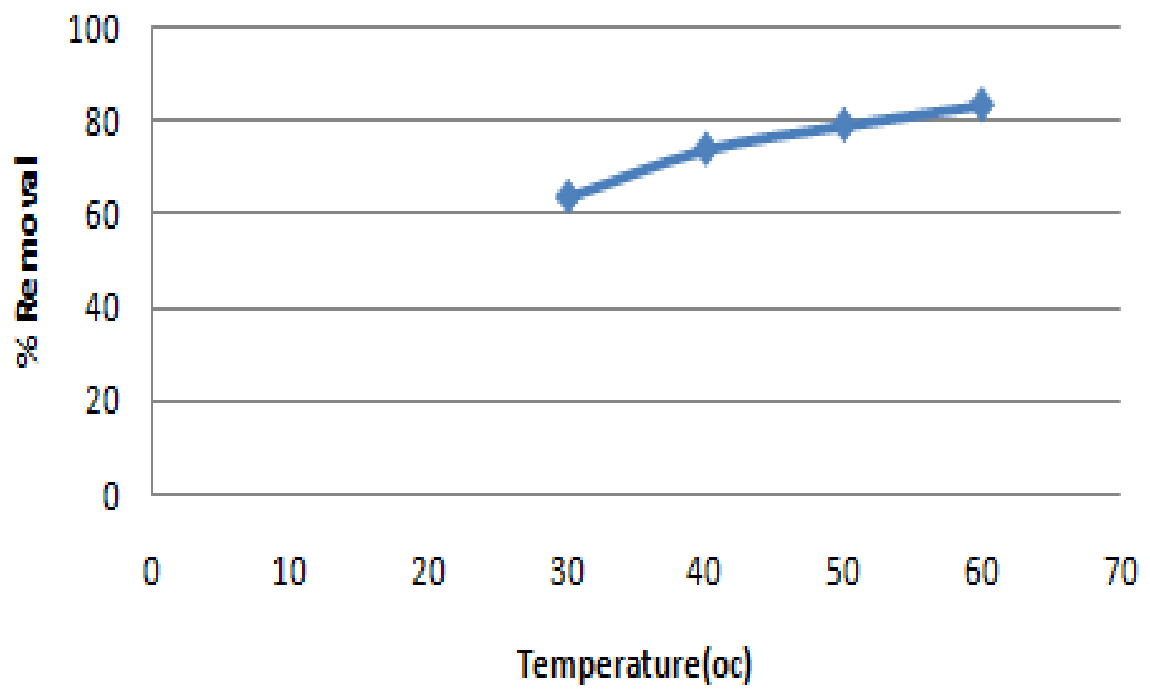

Figure1. Temperature effect for activated coconut shell carbon

\subsection{Effect of Temperature for Activated Montmorillonite}

The temperature dependence of fluoride adsorption by montmorillonite was studied over a range of $30^{\circ} \mathrm{C}$ to $60^{\circ} \mathrm{C}$ and at optimum conditions; contacts time of 50 minutes, $5 \mathrm{mg} / \mathrm{L}$ of fluoride initial concentration and $2 \mathrm{~g}$ of adsorbent. The percentage of adsorption of fluoride ions at 50 minutes was found to be $69.6,73.1,79.1$ and $81.7 \%$ at $30,40,50$ and $60^{\circ} \mathrm{C}$ respectively, Table 2 . The plot of temperature against fluoride adsorbed by the material at four different temperatures is given in fig 2 . The increase in the percentage of fluoride adsorption at higher temperatures confirms the endothermic nature of the process. 
Temperature Effects and Thermodynamic Adsorption of Flouride on Activated Coconut Shell Carbon, Activated Montmorillonite Clay and Rice Husk Ash

Table2. Showing the effect of temperature for activated montmorillonite clay

\begin{tabular}{|l|l|l|l|l|l|l|}
\hline Tem $\left({ }^{0} \mathrm{C}\right)$ & Absorbent $(\mathrm{g})$ & Time $(\min )$ & $\mathrm{C}_{\mathrm{i}}(\mathrm{mg} / \mathrm{L})$ & $\mathrm{C}_{\mathrm{e}}(\mathrm{mg} / \mathrm{L})$ & $\mathrm{C}_{\mathrm{i}}-\mathrm{C}_{\mathrm{e}}(\mathrm{mg} / \mathrm{L})$ & $\%$ Removal \\
\hline 30 & 2 & 50 & 5 & 1.522 & 3.478 & 69.6 \\
\hline 40 & 2 & 50 & 5 & 1.347 & 3.653 & 73.1 \\
\hline 50 & 2 & 50 & 5 & 1.043 & 3.957 & 79.1 \\
\hline 60 & 2 & 50 & 5 & 0.913 & 4.087 & 81.7 \\
\hline
\end{tabular}

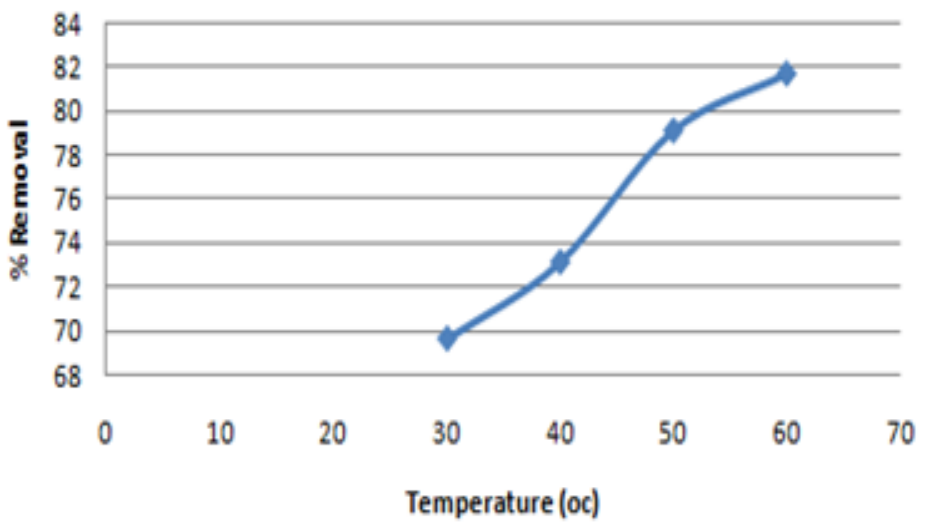

Figure2. Effect of temperature for activated montmorillonite

\subsection{Effect of Temperature for Activated Rice Husk Ash}

The effect of solution temperature was studied by conducting the experiment at different temperatures of $303,313,323 \& 333 \mathrm{~K}\left(30^{\circ} \mathrm{C}\right.$ to $\left.60^{\circ} \mathrm{C}\right)$ at optimum conditions; $5 \mathrm{mg} / \mathrm{L}$ of fluoride ion concentration, contact time of 50 minutes, dosage of $2.5 \mathrm{~g} / \mathrm{L}$ and $\mathrm{pH}$ of 2 . And the results obtained were plotted as percentage removal of the fluoride ion against temperature as shown in figure 3 . The percentage of fluoride adsorbed at 50 minutes was found to be 50.4, 55.7, 69.6 and $73.1 \%$ at the temperature of 30 , 40,50 and $60^{\circ} \mathrm{C}$ respectively, Table 3 . The increase in the percentage of fluoride adsorption at higher temperatures confirms the endothermic nature of the process [20].

Table2. Showing the effect of temperature for activated

\begin{tabular}{|l|l|l|l|l|l|l|}
\hline Temp $\left({ }^{\mathbf{0}} \mathbf{C}\right)$ & Absorbent $(\mathbf{g})$ & Time $(\mathbf{m i n})$ & $\mathbf{C}_{\mathbf{i}}(\mathbf{m g} / \mathbf{L})$ & $\mathbf{C}_{\mathbf{e}}(\mathbf{m g} / \mathbf{L})$ & $\mathbf{C}_{\mathbf{i}}-\mathbf{C}_{\mathbf{e}}(\mathbf{m g} / \mathbf{L})$ & \% Removal \\
\hline 30 & 2.5 & 50 & 5 & 2.478 & 2.522 & 50.4 \\
\hline 40 & 2.5 & 50 & 5 & 2.217 & 2.783 & 55.7 \\
\hline 50 & 2.5 & 50 & 5 & 1.522 & 3.478 & 69.6 \\
\hline 60 & 2.5 & 50 & 5 & 1.347 & 3.653 & 73.1 \\
\hline
\end{tabular}

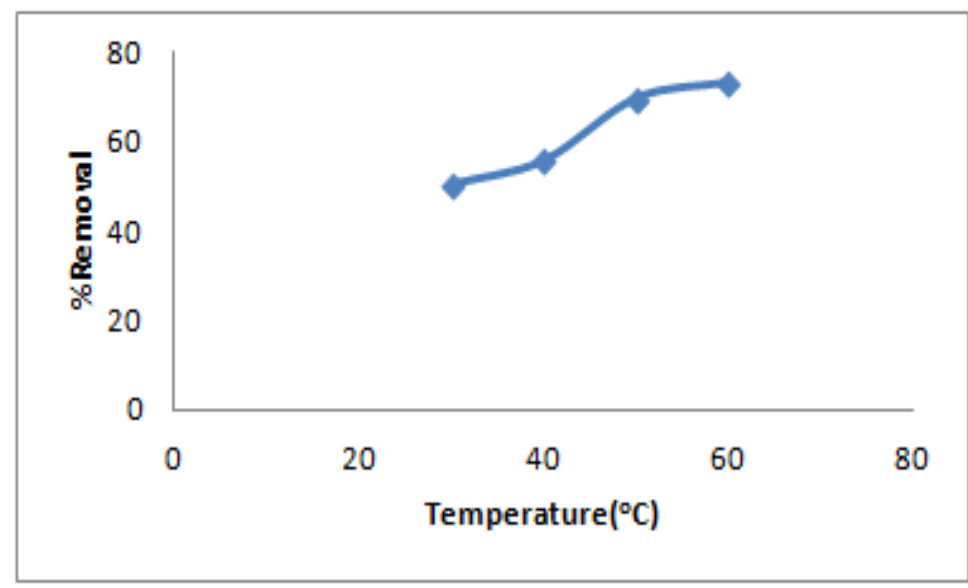

Figure3. Effect of temperature for activated rice husk ash

\subsection{Thermodynamic Evaluation of the Adsorption Process}

Thermodynamic parameters of the adsorption process such as change in free energy $\Delta \mathrm{G}(\mathrm{kJ} / \mathrm{mole})$, change in enthalpy, $\Delta \mathrm{H}(\mathrm{kJ} / \mathrm{mole})$ and change in entropy, $\Delta \mathrm{H}(\mathrm{kJ} / \mathrm{mole} / \mathrm{K})$ were determined at different temperatures by using the equation below; 


$$
\begin{aligned}
& \Delta \mathrm{G}=-\mathrm{RTInk}_{\mathrm{d}} \\
& \Delta \mathrm{G}=\Delta \mathrm{H}-\mathrm{T} \Delta \mathrm{S} \\
& \text { Inkd }=\Delta \mathrm{H} / \mathrm{R}-\Delta \mathrm{H} / \mathrm{RT}
\end{aligned}
$$

Where $\mathrm{T}$-temperature in Kelvin degrees

$$
\begin{aligned}
& \mathrm{R} \text {-Universal gas constant }(8.314 \mathrm{~J} / \mathrm{mole} / \mathrm{K}) \\
& \Delta \mathrm{S}-\text { standard entropy }(\mathrm{KJ} / \mathrm{mole} / \mathrm{K}) \\
& \Delta \mathrm{H}-\text { standard enthalpy }(\mathrm{KJ} / \mathrm{mole})
\end{aligned}
$$

The plot of Inkd versus 1/T gives a linear graph with the slope and intercept equal to $-\Delta H / R$ and $\Delta \mathrm{H} / \mathrm{R}$ respectively. The results for the thermodynamic parameters of the adsorption process such as change in free energy $\Delta \mathrm{G}(\mathrm{kJ} / \mathrm{mole})$, change in enthalpy, $\Delta \mathrm{H}(\mathrm{kJ} / \mathrm{mole})$ and change in entropy, $\Delta \mathrm{H}(\mathrm{kJ} / \mathrm{mole} / \mathrm{K})$ were presented in Table 4 . The value of the enthalpy change $(\Delta \mathrm{H})$ calculated from the slope were $-28808.01,-19388.25$, and $-31335.47(\mathrm{KJ} / \mathrm{mole})$ for activated coconut shell carbon, activated montmorillonite and activated rice husk ash respectively. The negative values of $(\Delta \mathrm{H})$ indicate the exothermic nature of the process. The values of the entropy change were found to be 123.62, 91.62 and $120.07(\mathrm{KJ} / \mathrm{mole} / \mathrm{K})$ for activated coconut shell carbon, activated montmorillonite and activated rice husk ash respectively. The positive values of entropy change suggest an increased randomness at the solid/liquid interface during the sorption of fluoride into the adsorbents, Amrani and Tazrouti, 2009. The calculated Gibbs free energy values for activated coconut shell carbon were found to be $-65355.87,-67501.07,-68737.27$, and $-69973.47(\mathrm{~kJ} / \mathrm{mole})$ at the temperatures of $303,313,323 \& 333 \mathrm{~K}\left(30^{\circ} \mathrm{C}\right.$ to $\left.60^{\circ} \mathrm{C}\right)$ respectively. For activated montmorillonite, temperatures of $303,313,323 \& 333 \mathrm{~K}\left(30^{\circ} \mathrm{C}\right.$ to $\left.60^{\circ} \mathrm{C}\right)$ the calculated Gibbs free energy were found to be -47149.11 , -

\begin{tabular}{|c|c|c|c|c|c|c|c|c|}
\hline Parameters & $\begin{array}{c}\Delta \mathrm{H} \\
(\mathrm{KJ} / \mathrm{mole})\end{array}$ & $\begin{array}{c}\Delta S \\
(\mathrm{~J} / \mathrm{mole} / \mathrm{K})\end{array}$ & \multicolumn{4}{|c|}{$\begin{array}{c}\Delta \mathrm{G} \\
(\mathrm{kJ} / \text { mole })\end{array}$} & $\mathrm{R}^{2}$ & Equation \\
\hline Temperature $(\mathrm{K})$ & & & 303 & 313 & 323 & 333 & & \\
\hline ACSC & $\begin{array}{l}- \\
28808.01\end{array}$ & 123.62 & -65355.87 & -67501.07 & -68737.27 & -69973.47 & 0.971 & $\begin{array}{l}Y=-3465 x \\
+14.87\end{array}$ \\
\hline AMMT & $\begin{array}{l}- \\
19388.25\end{array}$ & 91.62 & -47149.11 & -48065.25 & -48981.51 & -49597.71 & 0.99 & $\begin{array}{l}Y=-2332 x \\
+11.02\end{array}$ \\
\hline ARHA & $\begin{array}{l} \\
31335.47\end{array}$ & 120.07 & -67716.68 & -68917.38 & -70118.08 & -71318.78 & 0.84 & $\begin{array}{l}Y=-3769 x \\
+14.75\end{array}$ \\
\hline
\end{tabular}
48065.25, 48981.51, and 49597.71 (kJ/mole) respectively. And for activated rice husk ash, the calculated Gibbs free energy values were found to be $-67716.68,-68917.38,-70118.08$, and $71318.78(\mathrm{~kJ} / \mathrm{mole})$ at the temperatures of $303,313,323 \& 333 \mathrm{~K}\left(30^{\circ} \mathrm{C}\right.$ to $\left.60^{\circ} \mathrm{C}\right)$ respectively. The negative values of Gibbs free energy suggests the spontaneous and feasibility of the process, [20].

Table4. Thermodynamic parameters for adsorption of fluoride

ACSC: Activated coconut shell carbon, AMMT: Activated Montmorillonite and ARHA: Activated Rice husk ash

\section{CONCLUSION}

The temperature effects and the thermodynamic properties for adsorption of fluoride on various adsorbents; activated coconut shell carbon, activated montmorillonite and activated rice husk ash were studied. The study revealed that the removal percentage of fluoride increases with the increase in temperature for each adsorbent. The negative value of enthalpy for each adsorbent indicates the exothermic nature of the process while the positive value suggests an increased randomness at the solid/liquid interface during the adsorption of fluoride into the adsorbents.

\section{REFERENCES}

[1] Maheshwari R.C., and Meenakshi B. (2006). Fluoride in drinking water and its removal. Journal of Hazardous material, 137(1): 456-463.

[2] Barbier O, Arreola-Mendoza L, and Del R. L.M. (2010). Molecular mechanisms of fluoride Toxicity. Chemical and Biological Interaction, 188: 319-333.

[3] Amini M., Mueller K., Abbaspour K.C., Rosenberg T., Afyuni M., Moller K.N., and Johnson C.A.(2008). Statistical Modeling of global geogenic fluoride contamination in ground waters, Environmental Science Technology, 42:3662-3668. 
Temperature Effects and Thermodynamic Adsorption of Flouride on Activated Coconut Shell Carbon, Activated Montmorillonite Clay and Rice Husk Ash

[4] WHO(Ed), (2006).Guidelines for drinking-water Quality [Electronic Resource]: Incorporating first Addendum, Pp 375-377.

[5] Ayoob S., Gupta A.K. and Bhat T. (2008) "A conceptional overview on sustainable technologies for the defluoridation of drinking water". Journal of Environmental Science and Reseach, 38(2) 401-470.

[6] Aldaco R, Garea A, and Irabian A (2007). Calcium fluoride recovery from fluoride waste water in a fluodized bed reactor, Water resources, 41:810-818.

[7] Sehn P.(2008). Fluoride removal with extra low energy reverse osmosis membranes: three years of large scale field experience in finland, Deslination 223: 73-84.

[8] Meenakshi S, and Viswanathan N (2007) Identification of selective ion-exchange resin for fluoride sorption, Journal of Colloid interface Science, 308: 438-450.

[9] Kim, J.W., Sohn, M.H., Kim, D.S., Sohn, S.M. and Kwon Y.S.(2001). Production of granular activated carbon from waste walnut shell and its adsorption characteristics for $\mathrm{Cu}$ ion. Journal of Hazadous materials, 85(3), 301-315.

[10] Gogoi P.K. and Baruah R. (2008). Fluoride removal from water by adsorption on acid activated kaolinite clay, Indian Journal of Chemistry Technology, 15(5): 500-503.

[11] Tor A.(2006) Removal fluoride from an aqueous solution by using montmorillonite. Desalination, 201(1): 267-276.

[12] Kamble SP, Dixif P, Rayalu S.S., Labhsetwar N.K. (2009). Defluoridation of drinking water using chemical modified bentonite clay. Desalination, 249 (2): 687-693.

[13] Naba Kr M., Ria B., Arnab B., Jayanta Kr D., and Tanmoy B. (2012). A comparative study on the batch performance of fluoride adsorption by activated silica gel and activated rice husk ash, International Journal of Environmental Sciences, 2(3) 76-86.

[14] Gandhi N. D., Sirisha, K.B., Chandra S. and Smith A. (2012). Removal of fluoride from water and waste water by using low cost adsorbents. International Journal of Chem. Tech. Reseach, 4(4):1646-1653.

[15] Boundrahem F, Aissaini- Banissad H. (2009) " Batch sorption dynamic and equilibrium for the lead ions from aqueous phase using actvated carbon developed from coffee residue activated with zinc chloride (Zncl); Journal of Environmental Management 13(2) 35-38.

[16] Sugumuran P, Susan., Ravi Chandran V and Seshadri, S. (2012) "Preparation and characterization of activated carbon from banana empty fruit bunch and Dolomixregia fruit pod". Journal of sustainable Energy and Environmental 3(1) 125-132.

[17] Ekpete A.O and Horsfall, M.J.N.R. (2011) "Preparation and characterization of activated carbon derived from fluted pumpkin stem waste (Telfairioccidentalis Hook. F)". Reseach Journal for Chemical Science,1(3) 206-213.

[18] Olfat M.S., Safenaz M. R., Reemk, A. (2013) "Preparation and characterization of silica and coreshellnano-particles, advances in Nanoparticles, 2: 165-178.

[19] Dominic M.C.D, Sabura P.M.B., Joseph R., Daisy J., Prabith K., Aysuwaya E.P (2013). "Synthesis, characterization and applications of rice husk Nanocomposite in natural rubber". International Journal of Science Environment and Technology, 5(2):1027-1035.

[20] Amrani M. And Tazrouti N. (2009). Chromium (VI) adsorption onto sulphate lignin. Water Practice and Technology, 4(2):1-12.

Citation: D. Wilson et.al, "Temperature Effects and Thermodynamic Adsorption of Flouride on Activated Coconut Shell Carbon, Activated Montmorillonite Clay and Rice Husk Ash", International Journal of Advanced Research in Chemical Science (IJARCS), vol. 4, no. 9, pp. 21-27, 2017.

Copyright: () 2017 Authors. This is an open-access article distributed under the terms of the Creative Commons Attribution License, which permits unrestricted use, distribution, and reproduction in any medium, provided the original author and source are credited. 